\title{
Corporal Punishment in Nepalese School Children: Facts, Legalities and Implications
}

\author{
Mishra $\mathrm{N}^{1}$, Thakur $\mathrm{KK}^{2}$, Koirala $\mathbf{R}^{3}$, Shrestha $\mathrm{D}^{4}$, Poudel $\mathbf{R}^{5}$, Jha $\mathbf{R}^{6}$
}

${ }^{1}$ Dr. Navin Mishra, MBBS, MD (Paediatrics) Assistant Professor, Department of Paediatrics, KIST Medical College, Imadol, Lalitpur, Nepal, ${ }^{2}$ Mr. Kashi Kant Thakur, MBS, MA (Sociology), Project Officer, Environmental and Public Health Organisation, New Baneshwor, Kathmandu, ${ }^{3}$ Dr. Rabin Koirala, MBBS, MS (General Surgery), Associate Professor, Department of Surgery, KIST Medical College, Imadol, Lalitpur, Nepal, ${ }^{4}$ Dr. Devendra Shrestha, MBBS, MD (Paediatrics), Assistant Professor, Department of Paediatrics, KIST Medical College, Imadol, Lalitpur, Nepal, ${ }^{5}$ Dr. Rakesh Poudel, MBBS, MD (Paediatrics), Assistant Professor, Department of Paediatrics, KIST Medical College, Imadol, Lalitpur, Nepal, ${ }^{6}$ Dr. Rajanee Jha, MBBS, Medical Officer, Paropakar Maternity Hospital, Kathmandu Nepal.

Address for Correspondence: Dr. Navin Mishra, E-mail: mishranavin@hotmail.com, drnavin4@yahoo.com

\begin{abstract}
While the Convention on the Rights of the Child (CRC) demands that children be respected as human beings with the right to dignity and physical integrity, in Nepal corporal punishment is often considered necessary to children's upbringing, to facilitate learning and to instill discipline in the children. The existence of this cruel practice towards children is attributed to the weak national policy, unhealthy academic competition among the schools, poorly trained teachers, superstitious traditional beliefs and hierarchical social structure. Consequently, the children are doomed to suffer this practice resulting in negative physical, mental and social welfare. Besides corporal punishment, sexual abuse in school going children seems to be frequent but mostly unreported. This is high time we eliminated this violence against children in schools and it calls for holistic approach. For this, it is necessary to pursue a set code of conduct and raise awareness among the teachers for the child rights in order to stop undignified, inhuman and undisciplined tradition. The awareness and capacity of the health professionals to deal with complexities of the child abuse also needs to be promoted. Furthermore, the need of improvements in the national laws and their proper implementation is a longstanding challenge for the governmental and nongovernmental organizations.
\end{abstract}

Key words: child abuse, child rights, corporal punishment, psychological

\section{Introduction}

$\mathrm{C}^{\prime}$ hildhood is a delicate, sensitive and vulnerable period which requires considerate care and understanding. Ironically, this vital phase is overlooked in our society where most of the parents and teachers, by their very nature think that it is important to punish the children in order to tame their activities and to guide them to right track. This is evident from the study done by Shrestha and Thakuri in 2004, which reported that $60 \%$ teachers believe students, cannot be disciplined without punishment ${ }^{1}$. Similarly, a national survey carried out in Nepal by UNICEF ROSA in 2001 reported that 33 percent of the respondents were also victims of physical domestic violence ${ }^{2}$.
While the Convention on the Rights of the Child (CRC) in 1989 demands that children be respected as human beings with the right to dignity and physical integrity, only a modest change has taken place in this regard $^{3}$. Schools are still places of terror for a large number of students as the teachers have absolute authority. In addition, ill-trained teachers, who have little disciplinary options often, create such disgraceful circumstances.

The goal of education is to produce competent and healthy citizens who are familiar with national traditions, culture, democratic norms and can lead healthy 
meaningful lives. Corporal punishment has become an important tool in getting the best out of the student in an unhealthy milieu of parental expectation, competitive environment and a highly commercialized education sector.

Corporal punishment, as a means of discipline, is often taken for granted as an excuse to enforce obedience. Commonly practiced various ways of punishing school children, are listed in Box 14,5. However, these are just the milder forms. At times, we come across extreme cases. A math teacher in Pokhara took grade one students to the school toilet and made them touch human excreta with the tip of their tongues for not memorizing their tables. Similarly, UNICEF reported that a 10-year-old girl who was severely thrashed and hung upside down from the ceiling fan by the school principal because she was suspected to have stolen a fruit lying on the principal's desk, is now suffering from problems of hallucinations, depression and nightmares, and has discontinued her studies ${ }^{6}$. These types of cases are likely to be underreported for fear of shame and retribution.
The existence of corporal punishment and obvious supremacy over children by guardians or teachers clearly reflects low social status of children within the society, the family and in the classroom. Thus, it is a challenge to the Nepalese society to provide a caring environment for the children to nurture their talent; to provide a fertile ground for them to grow up as confident capable individuals that this country so desperately needs.

Besides corporal punishment in the schools, children are also victims of various ruthless traditional practices like early and forced marriage, dowry related abuse, sex slaves for priests and pilgrims, child labor and even child sacrifices to the altars ${ }^{7,8}$. Also sexual abuse in homes and schools is mostly unreported because of the lack of child protection standards and services, awareness in the community and the stigma attached to it $^{7}$. One of the bitter examples is of a nine year old school girl, who was repeatedly raped for over a year by the principal of a school in Kathmandu valley ${ }^{9}$.

Box1: Common punishment given to children in School ${ }^{4,5}$

Physical Punishments:

1. Beating: with a stick, cane, belt, pipe, fist, wet stinging nettles, duster etc.

2. Pulling ears and the hair of the temples.

3. Making them to stand up for the whole day in the sun.

4. Kneel down and do the work and then enter the class room.

5. Making them stand up on the bench.

6. Making them to raise hands.

7. Pressing a pencil between two fingers.

8. Holding their ears with hands passed under the legs.

9. Tying their hands.

10. Making them to sit-ups.

11. Caning and pinching cheeks or arms.

Emotional Punishments:

1. Slapping by the opposite sex.

2. Scolding, abusing and humiliating.

3. Giving animal names: donkey, monkey, ox, bitch, buffalo.

4. Calling parents to the school.

5. Suspending them for a couple of days.

6. Pinning paper on their back and labeling them "I am a fool".

7. Ordering students especially girls to stand in the rain.

8. Making student stand completely naked in the classroom.

Negative Reinforcement:

1. Detention during the break and lunch.

2. Locking them in a dark room.

3. Asking the children to bring explanatory letters from the parents.

4. Sending them home or keeping the children outside the gate.

5. Making the children sit on the floor on the classroom.

6. Making the child clean the premises.

7. Giving oral warnings and letters in the diary or calendar.

8. Sending the children to the principal.

9. Making them teach in the class.

10. Making them stand till the teacher comes. 


\section{Corporal punishment in Nepal}

Although very little survey exists in this context, testimonies from students, parents, teachers, as well as reported incidences in the media, suggest that corporal punishment is a common problem in many schools in the region ${ }^{10-12}$. In this regard Child Workers in Nepal Concerned Centre (CWIN) has been publishing a periodic report on the status of the rights of Nepali children since $1996^{13}$. As per the annual data provided by CWIN, the annual prevalence of common forms of child abuse is depicted in Figure $1^{13-18}$. In year 2009 CWIN reports that among total 5249 cases of child abuse, 112 cases were of corporal punishment, 12 cases of domestic violence and 97 cases of killing of infants and children ${ }^{14}$. In spite of the increasing national and international initiatives there has been no significant improvements as seen in the following graph regarding the child status over the past six years. Instead, there has been a significant rise in reported incidence of the child labor in the last two years.

The CWIN Helpline receives an average of 35-40 calls a day from children or concerned individuals asking for help ${ }^{19}$. It is to be noted that the incidents mentioned above represent only a tip of the iceberg as the majority of the incidents do not come to light and are unreported or repressed.

A survey of Nepal Human Development Report in 1998 revealed that 63 percent of students dropped out of school before the completion of primary grade and another 27 percent dropped out from the lower secondary level ${ }^{20}$.One of the contributing factors for this was the use of corporal punishment and verbal humiliation in the schools. In Nepal, as much as $14 \%$ of children claim to have dropped out of school because they were afraid of their teachers ${ }^{21}$. Gender violence has also been attributed as a cause of poor performance and students dropping out, however the study did not examine into the absolute causes of school dropping out ${ }^{22}$. Besides corporal punishment, sexual abuse in school going children is rampant in our society. It is not uncommon in media to hear that teachers and near relatives among the abusers $^{23,9}$. A survey done in 1996 revealed that $13 \%$ of respondents knew about at least one case of child sexual abuse in their surroundings ${ }^{24}$. The study also revealed that $64 \%$ of abused were below 16 and $9 \%$ among them were victims of incestuous rape. There is evidence of abuse in schools precincts as well. A research published in 2006, conducted in four districts of Nepal by UNICEF and CWIN, found that nearly 18 percent out of the 4,100 students had experienced contact sexual abuse, among which $17.6 \%$ occurring in school and among non contact form obscene language was most common $44.5 \%$, followed by obscene materials in $28.8 \% 25$. In the same study nine percent has experienced sexual abuse of serious nature that included kissing private parts, oral sex and penetration ${ }^{25}$. Similarly a survey done by UNVAC in Nepal found that almost 14 per cent of child respondents had been fondled or kissed, and 15 per cent of these children had experienced this in the school grounds $^{26}$. In the same survey, nine per cent of children experienced more serious forms of sexual abuse, such as oral sex or penetration, 17.5 per cent said that it took place at school. Another research report on child sexual abuse in 2003 by Save the Children Norway in Nepal and CWIN, reported that nearly 13.7 percent of the 5,000 interviewed students had suffered from severe sexual abuse in Kathmandu valley. Also eight percent of girls and six percent of boys named family members as abusers $^{27}$.

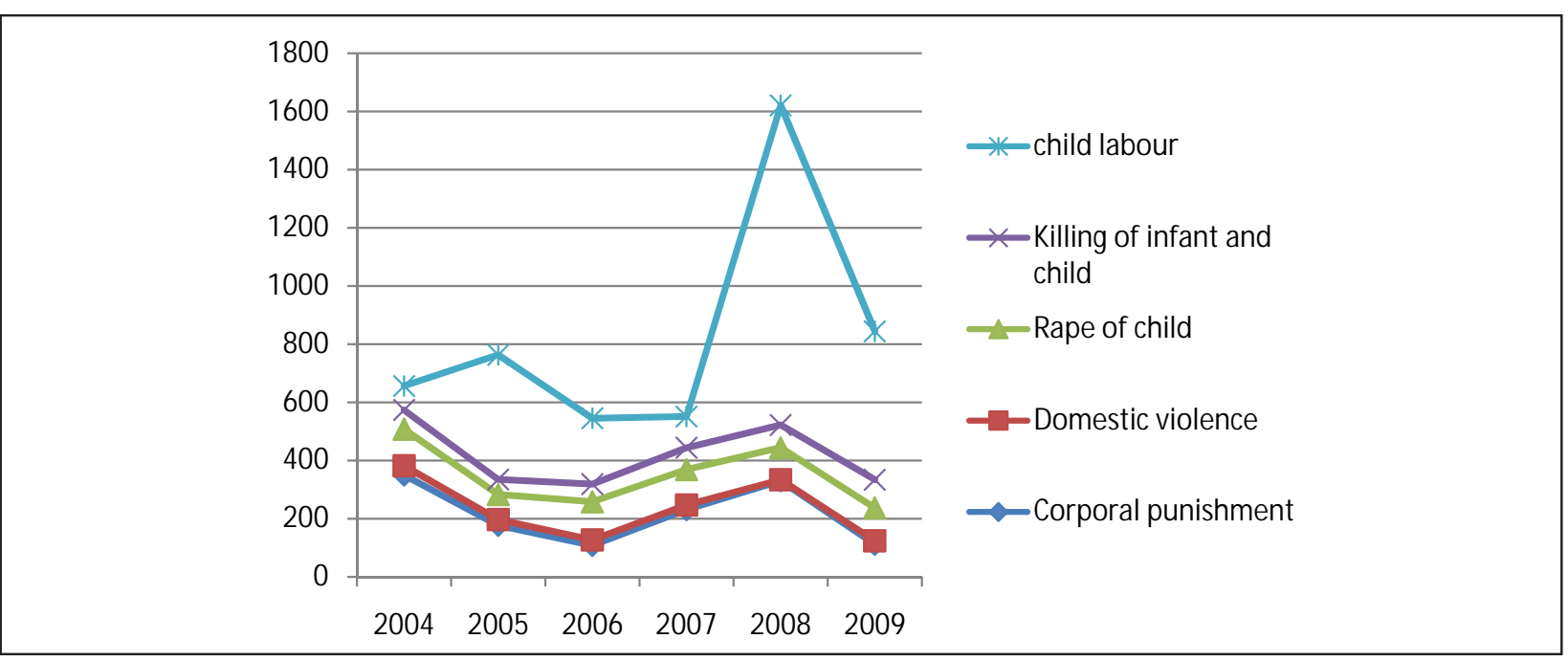

Fig. 1: Showing the annual prevalence of common forms of child abuse. 


\section{Corporal punishments in other countries}

The problem is common both in developed and developing countries ${ }^{28-32}$. As per the Global initiative to End All Corporal Punishment of Children, 90 countries continue to allow teachers to legally use corporal punishment and even in the countries where corporal punishment is legally banned, it is often poorly enforced ${ }^{33}$. Corporal punishment is still not legally banned in schools even in developed countries like Korea, France and a number of Australian and some of the states of America. In Singapore corporal punishment of school boys is legal but it is illegal for teachers to hit girls ${ }^{32}$.

The UN Secretary General's Study on Violence against Children reported that only $2.4 \%$ of the world's children are legally protected from corporal punishment in all settings ${ }^{34}$. One million children are affected by school violence each day ${ }^{32}$. An Indian study of 13 states revealed that two out of every three children were physically abused and every second child was emotionally abused ${ }^{35}$. Out of the physically abused children $88.6 \%$ were physically abused by parents and two out of every three children were victims of corporal punishment in schools. This study also revealed that $53.22 \%$ children faced one or more forms of sexual abuse among which $21.90 \%$ child respondents reported facing severe forms of sexual abuse while $5.69 \%$ were sexually assaulted ${ }^{35}$.

InAfghanistan, 82\% of children interviewed reported being slapped, kicked and caned in their schools ${ }^{2}$. In Sweden, $49 \%$ of girls felt that there was some form of sexual harassment at school while in the Netherlands; $27 \%$ of students reported being sexually harassed by school personnel ${ }^{32}$.

In the same way, a study from Zimbabwe in 2001 revealed that out of 246 reported cases of abuse by teachers in secondary school, $65.5 \%$ were cases of sexual intercourse with pupils, $1.9 \%$ cases of rape or attempted rape and the remaining were the casesof inappropriate teacher conduct (writing love letters, fondling, kissing and showing pornographic materials to pupils) ${ }^{36}$. A survey of violence against women from Ghana revealed that $4 \%$ of sexual assaults on adolescent girls were by fellow pupils and $2 \%$ by teachers ${ }^{37}$. Research in Uganda showed that eight per cent of 16 and 17 year-old boys and girls questioned had had sex with their teachers and 12 per cent with ancillary staff ${ }^{38}$. In Ecuador, a study of female adolescent victims of sexual violence found that 37 per cent named teachers as perpetrators ${ }^{38}$. In South Africa; schoolteachers were found guilty of one-third of child rapes ${ }^{39}$.
Even in the countries which have abolished corporal punishment in schools it is still being widely practiced for example in China and in Pakistan ${ }^{40-42}$. In a Chinese study conducted on 6592 students, prevalence of parental psychological aggression, corporal punishment, severe physical maltreatment and very severe physical maltreatment in the last six months were noted in $78.3 \%$, $23.2 \%, 15.1 \%$ and $2.1 \%$ respectively ${ }^{41}$. The commonly cited reasons for maltreatment in this study include disobedience, poor academic performance and parental disputes.

A study done in three districts of North West Frontier Province in Pakistan in 3,582 children aged 6-14 years revealed about $43 \%$ of all punishments identified were reported by children in government primary schools, about $30 \%$ in government middle schools, $10 \%$ in government high schools, and $16 \%$ in private schools. Among the corporal punishment inflicted in homes, immediate family members such as parents (20.22\%), grandparents (24.04\%) and older siblings (18.91\%) and uncles and aunts (27.31\%) were the most common culprits ${ }^{42}$.

However, Sweden which has banned corporal punishment since 1979 has maintained a very low rate of child abuse for more than 25 years ${ }^{43}$.

\section{Why children are suffering in schools}

\section{Weak National Policy}

Though Nepal has ratified the UN Convention on the Rights of the Child (CRC) in 1990, there is no explicit prohibition of corporal punishment ${ }^{9}$. The Civil Code (Muluki Ain, 1963) states that guardians and teachers shall not be held responsible for grievously hurting a child in the course of education or defense. Section 7 of the Child Act (1992, in force 1993) states that "no child shall be subject to torture or cruel treatment" but also states that "any act by the mother, father, family member, guardian or teacher to scold the child or give him/her minor beating for the sake of his or her interests shall not be deemed to have violated this Section"44. However, following a writ petition filed by the Centre for Victims of Torture in Nepal on 16 June 2004, the Supreme Court ruled that the restrictive clause in section 7 was unconstitutional and declared the portion "or give him/her minor beating" null and void with immediate effect ${ }^{45}$. Still, there is no explicit prohibition of corporal punishment in schools in the Education Act (1971, amended 2004) or the Education Regulation (2003), though the Child Act prohibits harsh punishment ${ }^{46}$. Though legal defense available to teachers was removed in 2005 by the 
Supreme Court ruling, but it continues to be widely used, particularly in private schools ${ }^{46}$.

Recently government has showed commitment against corporal punishment in school in its School Sector reform Plan 2009-2015 stating that teachers shouldn't apply any form of corporal punishment in schools $^{47}$. But it is not enough to have laws unless they are enforced. However, if we review Nepal Government's commitment, it has become a famous package with little outcome. Also, in absence of adequate and appropriate policy guidelines, referral system, implementation and monitoring mechanism there is little accountability.

The loop holes in this law are liable to be misused by guardian, teachers or parents. The prevalent law doesn't differentiate physical discipline, corporal punishment and physical abuse. There is paucity of research in this regard. One such study entitled "Crossing the line from physical discipline to child abuse: how much is too much?" conducted by Whipple and Richey to differentiate physical discipline and child abuse in home found that abusive parents spanked their children more often than the non-abusive parents and aggregated data from non-abusive parents used to compute a normal range of daily spanking frequencies from 0 to 5.7 times in 24 hours ${ }^{48}$. More studies are required to define physical discipline and physical abuse in school to implement the laws effectively.

\section{Traditional Culture}

The concept of "respect for the elders" is commendable in its own right but the society's hierarchical set up has resulted in unequal power, respect and relations based on gender, class and ethnicity. This has manifested as oppression and violence against weaker sections of the society. Violation of children rights is also a product of our cultural values. For example, the verses of Chanakya, a famous Hindu philosopher has mentioned in Chanakya Neeti -"Lalnaad bahbo dosas tadnad bahabo gunah, Tasmat putram cha sisyam cha tadaet na tu lalyed" which means excessive affection breeds flaws and admonition good qualities ${ }^{49}$. This practice is rooted to such an extent that parents who are unable to handle their children give schools permission to carry out such disciplining tactics. Many students see corporal punishment as a normal feature of their education. Interviews with teachers and children in Kathmandu, conducted by UNICEF reported that some of the children said that "it happens and we accept it as normal because if we do something wrong then we must be punished"50. Thus, some of the children have been habitual of such traditional practice.
Sex is a taboo subject in the Nepalese society. Sex education at schools is practically non existent. Ignorance of the children and the stigma associated with sexual abuse has allowed these acts to flourish in schools and at home. In addition, superstition like the sexual intercourse with a virgin may be a cure for sexually transmitted disease has resulted in child rape in this region as well as in African countries ${ }^{51,52}$.

\section{The Home Environment}

A strong knit patriarchal family that is meant to look after its children well has seldom had the realization that children are individuals with their own rights ${ }^{53}$. Children are generally seen as immature and the assumption is made that adults know the best and thus must make decisions about children's lives. Acceptance of the need for physical punishment in schools as a way of teaching and instilling discipline in children may be perpetuated by parents, particularly fathers in the belief that in the absence of corporal punishment, children will go astray.

\section{School System}

The country has around 31,156 schools as of 2009 end among them more than 8,500 are private schools and the remaining are government run ${ }^{54,55}$. In December 2003, CVICT, in collaboration with UNICEF, conducted a focus group study on "Existing Systems of Discipline in Schools" revealed the fact that corporal punishment was being used in most schools, more commonly in the private than in public schools ${ }^{56}$. As the government schools runs sort of the basic facilities such as school buildings, furnitures and other infra structure, there is rush of students and parents to join the private schools which implement rigorous disciplinary measures to ensure their better results and high success stories. These private schools have mushroomed with the sole purpose of making money. The School Management Committees seldom, if ever, discuss on policies formulation and other management from the perspective of the rights of the child rather they remains busy in auditing financial progress which is evidenced in the study by Shrestha and Thakuri in which $65 \%$ of school never discussed corporal punishment as an issue ${ }^{1}$. It is often observed that the only indicator of a schools strength in education is their results in school Leaving Certificate (SLC) exams and Higher Secondary Board Exams. For this corporal punishment is considered a key element in enhancing student performance and so the schools are generally seen imposing very strict discipline leading to stringent actions even against the minor violations of school rules. The failure of educational authorities to acknowledge the existence of such punishment and to address the same effectively in the background of weak policy compliance, 
low resources and entrenched gender roles has allowed it to flourish unchecked and to become institutionalized. Politicization and government interference in the running of these schools has resulted in little or no change in the system.

\section{Poorly Trained and Unprofessional Teachers}

In Nepal by the end of 2009 there are 2, 07,567 teachers with student to teacher ratio of $34: 1^{54}$. A survey revealed that only 30 per cent of primary teachers are trained ${ }^{57}$. Poorly trained or untrained teachers are unable to address the diverse learning demands of children in the classroom and thus make the learning tedious for the child. The common reasons why teachers offer punishment is outlined in Box $2^{37}$. Also, poor working conditions and insufficient beneficiaries to the teachers inhibit the flow of suitable individuals to the teaching profession and thus making teaching as the last choice of profession for the people in Nepal. Since the teachers are considered as a figure of authority and has to be obeyed while the students should adjust and comply has perpetuated the corporal punishment. In fact teachers are role models to the students and there should be symbiotic relationship with student rather than behaving as figures of authority.

Box 2: Why a teacher punishes children in school: ${ }^{37}$

1. Not coming to school in neat school uniforms.

2. Not coming to school on time.

3. Not doing their homework.

4. Not paying school fees promptly.

5. Not respecting teachers.

6. Not memorizing an assigned lesson.

7. Misbehaving, fighting or quarrelling in class.

8. Disturbing class or falling asleep in class

9. Destroying school's property.

10. Writing unacceptable things on the school premises.

11. Skiping classes.

12. Failling in an examination.

13. Stealling something.

14. Forgetting to bring stationeries in classroom

15. Fail in an examination.

16. Cheating in exams.

\section{Consequences of Corporal Punishment}

A good protective environment that fosters learning and inquisitiveness is extremely important for a child's growth. A hostile environment during child hood has serious long term consequences.

A common effect of corporal punishment is a growing fear of teachers among school children and dislike towards school. Harsh discipline hampers children's motivation and ability to learn leaving them in a vicious circle of low achievement, repetition, rejection and ultimate withdrawal from the educational process $^{58}$. Such sort of impact on child psychology has also been supported by a study from Yemen which has shown that corporal punishment is associated with poor school performance and both behavioral and emotional disturbances ${ }^{28}$. In the same way, study from United States reported 64 per cent of the states allowing school corporal punishment have an education level lower than the national average ${ }^{59}$. Also, an Australian study revealed that the corporal punishment by parents too was shown to be significantly associated with psychological maladjustment in children and this association was enhanced by child witnessing or experiencing violence from community, teacher and peer ${ }^{60}$.

Also it can produce feelings of helplessness, guilt, violation, loss of control and lowered self-esteem ${ }^{61}$. Children who are subjected to physical punishment behave more aggressively than those who are not. Studies show that child abuse and physical violence in the early years contribute significantly to a higher risk of children turning violent to themselves ${ }^{62}$. Beating a child not only causes pain, injury and at times permanent disability and mental health problems but has also been linked to an increased tendency for suicide or homicide. Abused children often have higher lifetime prevalence of suicide ideation and disability than the general population ${ }^{63,64}$. This effect seems to last till later years ${ }^{65,66}$. Various reported incidents of suicide in school children of Nepal have been attributed to this ruthless approach of disciplining child ${ }^{47}$. Also in United States, murders committed in schools are significantly more frequent in the states authorizing corporal punishment than in others ${ }^{32}$.

Various consequences due to corporal punishment have been outlined in Box $3^{4,67}$. 
Box 3: Consequences of Corporal Punishment ${ }^{4,6}$

\section{PSYCHOLOGICAL CONSEQUENCES}

- Poor concentration

- Loss of creativity and self esteem

- A loss of interest in studies.

- Feelings of helplessness, demoralization.

- Inferiority complex.

- Lethargy, lack of expression.

- Phobia

- Personality disorders

- Hallucinations,

- Anxiety and panic attack,

- $\quad$ Eating and sleep disorders

- Depression

- Alcohol and drug abuse

- $\quad$ Suicide

- Hysteria

\section{SOCIAL CONSEQUENCES}

- Creation of an uncivilized environment

- $\quad$ Death

- Gang formation.

- Anti-social activities.

- $\quad$ Feelings of disrespect for teachers.

- Destruction of public property.

- Taking revenge of punishment in school.

- Involvement in destructive activities.

- Becoming drug addicts.

- Disobeying elders, parents and teachers.

- School dropout

- $\quad$ Finding it difficult to adjust.

- $\quad$ Social activity hampered.

\section{CONSEQUENCES FOR TEACHERS}

- Teachers lose their jobs.

- $\quad$ Students take revenge, threats from students and parents.

- $\quad$ File case in court against teachers by parents.

- Transferred to another school.

- Worsening of relationships with parents and students.

- $\quad$ Required to pay medical compensation for treatment.

\section{Majors to safeguard the children form the corporal punishment}

Time has come to reexamine the saying "Spare the rod and spoil the child". The best way to stop this practice is through a holistic approach at different levels.

\section{Improving class room environment}

Within the classroom, teachercanaddressautonomy need of children by allowing students choice and input on classroom decision-making. Positive interpersonal behavior of teachers/administrators and supportive social context in school can enhance intrinsic motivation and self-regulation in school work of adolescent student. As per the basic need theory, autonomy, competence and connectedness are the basic psychological need of human beings ${ }^{68}$. Students need to feel competent and autonomous to maintain their intrinsic motivation-selfregulation in learning whereas the need for relatedness is also crucial for internalization. Students fulfilling these three categories of needs become psychologically healthy.

In a study done in schools of Kathmandu valley to identify children's motivational patterns in academic activities and level of their autonomy need fulfillment it was noted that autonomy need of the school children, was not fulfilled (Relative autonomy index $=-0.83$ ) and that prevalent extrinsic motivation in school has adverse effects in mental health of the students ${ }^{69}$. Therefore, for the promotion of psychological well-being, better personality development and higher achievement, methods for identified regulation should be practiced more in the Nepalese context.

It is imperative to include issues of gender equality, rights and power relations as part of the school curriculum. Teaching methods, which are generally teacher-centered with little recognition of children's perspectives, need to be changed making it child friendly ${ }^{58}$.

Adoption of child-centered approach in teachinglearning process can effectively assess the learning needs and capacities of a child. It will promote the child's participation in all aspects of school life and takes into account the diversity of learning needs and also the various support and methodologies required to match the mode and pace of 'Joyful Learning' for each child ${ }^{61}$. If child is not responding to teaching or defying the instruction, it could be mostly a question of psychology of that child, which the most of the teachers in school do not understand. Hence, teachers should know about the rights of the child and the principles of child psychology and development. Sometimes an individual based approach is needed to be adopted in understanding the specific cases and shape the child up to the requirements. These children, instead of the corporal punishment, require special medical care. 


\section{Local Initiatives}

School-wide interventions is found to be most effective form of lowering the violence rate in schools ${ }^{70}$. A study from United States on 544 schools showed that the school environment has significant impact on the successful establishment of intervention programmes ${ }^{71}$.

A key component of a school-wide approach is clear management standards ${ }^{72}$. Hence, a common framework should be established to tackle the violence. Training to teachers, healthcare professionals, judicial and police personnel, especially to women staff, regarding the identification of children affected by sexual violence is necessary. A study from African countries where school corporal punishment often persists in the name of tradition it was found that teachers receiving training on alternative discipline methods are generally more favorable towards corporal punishment abolition than teachers who have not received such training ${ }^{33}$. The implication is that the teachers and parents need to be sensitized for their required attitudinal change towards the majors of disciplining the children. Education department needs to be equipped with necessary personnel who can study the reasons of specific behavior shown by a child or a teacher.

Also, children's participation in meetings on issues, like dealing with functioning, governance and maintenance of facilities at school should be encouraged. Child Right committee in school can play a significant role in checking physical assaults. Likewise, parent association can play a major role in checking management of school in respect of children handling ${ }^{5}$.

\section{Role of the Health sectors}

Health care systems can help in reducing the consequences of violence by providing services to the survivors as well as providing training to care providers in such cases. Health care providers can contribute extensively by taking care of physical, mental and social well-being of children. They need to promote disciplining strategies to facilitate positive parent-children as well as teachers-students relationship and to boost up children's self-esteem and maintain healthy competition ${ }^{73}$. They need to understand the context of abuse, identify signs of abuse and provide sensitive and empathetic care by counseling to the suffering children.

The awareness and capacity of health professionals to deal with complexities of child abuse is dismal in Nepal. A study done by UNICEF in Nepal revealed that very few health practitioners reported actual dealing with child abuse cases and among 264 health workers only 10 health practitioners knew about the "Battered child syndrome"74. Surprisingly in the same study many health professionals responded that it was not their responsibility to report child abuse cases and they think their duty was to provide treatment only. Only about half of the total respondent felt comfortable administering care to physically abused children. Likewise, out of 82 health practitioners, who responded to have undertaken the actual actions when dealing with abuse cases, about $17 \%$ reported to have offered treatment to physical injuries only while about $45 \%$ provided guidance and counseling too. The availability of Rape Kit (which contains instructions and a check off sheet, material necessary to gather blood, semen, hair, saliva etc. to confirm the rape cases) was known to only $0.8 \%$ of medical professional ${ }^{74}$.

Hence, the capacity of health sector and health personnel for managing the abused survivors needs to be strengthened. This requires creating awareness of this issue among health practitioners by proper trainings. Also, the appropriate integration of these issues into health service in the districts should be done appropriately. They should be prepared with the skills not only related to physical treatment but also should be able to provide psychotherapy and rehabilitation as well. The medical courses taught in Nepal focus mainly on clinical diagnosis and treatment of patients giving little importance on social problems like child abuse. Therefore incorporation of issues of child right and child abuse in medical course seems necessary.

\section{Initiatives from Governmental and Non- Governmental Organizations}

The national law does not support corporal punishment to adult except criminal cases. Paradoxically, the law of land keeps children subjected to physical thrashing by elders for disciplines. The government should address the problem through its policies and programs at various levels. Provisions of child right protection should be made the part of constitution to be drafted in days to come. Concerned ministries should have strict policies on code of conduct for teachers and budget allocation should be secured in the relevant sectors as an expression of political will and commitment to protect boys and girls. Public awareness must be raised against the corporal punishment and verbal humiliation and the negative consequences of such physical and psychological abuses on children should be exposed. Also programs tackling sexual violence needs more indepth evaluation to inform policy makers.

Recently, the Ministry of Education which has announced formal launching of 'Learn without Fear' campaign nationwide in order to promote learning with 
dignity $^{47}$. "Children are Zones of peace" campaign is being carried out to create awareness about children's rights $^{14}$. These efforts need to have continuity.

Child Workers in Nepal (CWIN), the first child rights organization working since 1987 in Nepal, provides reports on violation of child right in order to alarm the society in this context. Similarly, National Private and Boarding Schools' Association Nepal (NPABSAN) has also been launching anti-corporal punishment training for teachers ${ }^{75}$. Moreover, various international organizations have been playing a vital role in developing country for the protection of child right by providing support for identifying the problems and extending financial and moral support. For example, United Nations Educational, Scientific and Cultural Organization (UNESCO) is involved in an international anti-violence initiative in schools called Living Value Education ${ }^{76}$. The program provides activities, methodologies and materials for teachers and facilitators to use while dealing with young people ${ }^{76}$. Similarly, United Nations Girls' Education Initiative (UNGEI) held meeting has anticipated developing a world where all girls and boys would be empowered through quality education to realize their full potentials enabling them to contribute in positive transformation of societies ${ }^{77}$.

\section{Conclusion}

Though, unspoken corporal punishment is a common problem in Nepal. In view of the gravity of the situation, the studies conducted in such a highly sensitive and significant aspect of social concern are still very limited. Though various organizations have recently taken up this issue but a lot still needs to be done in this regard. Hence, anticipating the fact that the environment of the childhood determines the shape of their future personality, an integrated effort from all sections of the society, institution and concerned authority must provide a conducive environment where the children can develop themselves at their best.

\section{References}

1. Shrestha S, Thakuri S (ed). Corporal Punishment in School: Hatamalo Sanchar. Kathmandu: Hissi Offset Printers; 2004. p. 23-50.

2. Global Initiative to End All Corporal Punishment of Children. The nature and extent of corporal punishment- prevalence and attitudinal research in South Asia. http://www.endcorporalpunishment. org/pages/pdfs/prevalence/SouthAsia2008.pdf. Published March 2008. Accessed March 2, 2010.
3. OHCHR. Convention on the Rights of the Child. http://www.ohchr.org/english/law/crc.htm\#art19. Published 1989. Accessed February 4, 2010.

4. CVICT/ UNICEF. Violence against children in Nepal. A Study of the System of School Discipline in Nepal. http://www.unicef.org/nepal/Voilence_ Against_Children_series_2.pdf. Published 2004. Accessed February 4, 2010.

5. Sridhar M. Corporal punishment: Violation of child rights in schools. http://www.legalservicesindia. com/articles/punish.htm. Assessed February 4, 2010.

6. Jabeen F, Karkara R. Mapping Save the Children's Response to Violence against children in South Asia. Save the Children, Sweden. http://sca. savethechildren.se/upload/scs/SCA/Publications/ Mapping\%20of\%20Save\%20the\%20Childrens\%2 Oresponse \%20on\%20violence\%20against\%20chil dren.pdf. Published 2006. Accessed February 10, 2010.

7. Save the children. Regional program for South and Central Asia Child Protection http://sca. savethechildren.se/sca/Our_work/ChildProtection/. Accessed February 24, 2010.

8. Mikeldunham. Agence France.Child Sacrifice in Nepal; FourMenArrested. http://www.mikeldunham. blogs.com/mikeldunham/2010/02/child-sacrificein-nepal-four-men-arrested.html. Published 2010. Accessed February 12, 2010.

9. CWIN. State of the Rights of the Child In Nepal 2001. CWIN Kathmandu. http://www.cwin.org.np/ resources/reports/roc2001.pdf. Published 2001. Accessed February 12, 2010.

10. Student Tortured in school. Kantipur Daily. September 1, 2006.

11. Student locked in Toilet. Nepal Samachar Patra. September 15, 2006.

12. Exploitation in Boarding School. Gorkhapatra Daily. September 18, 2006.

13. CWIN. The state of the Rights of child in Nepal Annual Report Jan-Dec 2004/ National Report. CWIN Kathmandu. http://www.crin.org/ docs/resources/treaties/crc.39/Nepal_CWIN_ nationalstatusreport1.pdf. Published 2005. Accessed February12, 2010. 
14. CWIN.The state of the Rights of child in Nepal Annual Report-Jan-Dec 2009/ National Report. Kathmandu: CWIN; 2009.

15. CWIN.The state of the Rights of child in Nepal Annual Report Jan-Dec 2008/ National Report. Kathmandu: CWIN; 2008.

16. CWIN.The state of the Rights of child in Nepal Annual Report Jan-Dec 2007/ National Report. Kathmandu: CWIN;2007.

17. CWIN.The state of the Rights of child in Nepal Annual Report Jan-Dec 2006/ National Report. Kathamndu: CWIN; 2006.

18. CWIN.The state of the Rights of child in Nepal Annual Report Jan-Dec 2005/ National Report. Kathmandu: CWIN; 2005.

19. Silence of the lambs keeping quiet about child abuse only results in the re-victimisation of children. Wave Magazine July 2006; issue no 127. http:// www.wavemag.com.np/issue/article1829.html. Assessed February 24, 2010.

20. Nepal Human Development Report 1998, Nepal South Asia Centre, Kathmandu May 1998, page 78.

21. CVICT. Discipline with dignity. http://www.cvict.org. np/disc.html2. Published 2008. Assessed February 24, 2010.

22. Dunne M, Humphreys S, Leach F. Background paper prepared for the Education for All Global Monitoring Report 2003/4 Gender and Education for All: The Leap to Equality Gender and violence in schools. 2003.

23. Nepal: Risks of child sexual abuse growing. IRIN News. Published Jan 21, 2008. http://www.irinnews. org/Report.aspx?Reportld=76342. Accessed February 20, 2010.

24. SAATHI The Asia Foundation. A Situational Analysis of Violence against Women and Girls in Nepal. Kathmandu: SAATHI; 1997.

25. UNICEF/CWIN: Child Sexual Abuse in Nepal: Children's Perspectives with reference to study in four districts. http:// www.un.org.np/reports/UNICEF/2006/20064 - 5 - Violence Against Children In NepalReport\%20Series_1-uptated.pdf. Published 2006. Accessed February 12, 2010.

26. United Nations. Violence against children: regional consultation in East Asia and the Pacific. Geneva: United Nations; 2005.
27. CWIN/ Save the Children Norway. Silent Suffering: Child Sexual Abuse in the Kathmandu Valley. Kathmandu: CWIN; 2003.

28. Alyahri A, Goodman R. Harsh corporal punishment of Yemeni children: occurrence, type and associations. Child Abuse Negl 2008;32:766-73.

29. Government of Bangladesh/ UNICEF/ Save the Children Alliance. Child Abuse Study: Study Report, Draft Version 2005 January 25.

30. UNICEF/NCPCA.What does it show on the state of corporal punishment in India? http://www.ncpcr. gov.in/Reports/Research_SN_16_Feb_09.pdf. Published 2009. Accessed February 12, 2010.

31. Save the Children/UNICEF/NWFP. Disciplining the Child: Practices and Impacts: April 2005.

32. Bazan C.School violence and gender: What the evidence says. Plan international Learn without fear Web site. http://www.learnwithoutfear.de/pdf/ Cesar-Bazan-Plan-International.pdf. Published 2008. Accessed March 5, 2010.

33. The global campaign to end violence in schools. Plan International Web site. http://plan international. org/learnwithoutfear/files/learn-without-fearglobal-campaign-report-english. Published 2008. Accessed February 22, 2010.

34. UNICEF/ Interparliamentary Union. Eliminating violence Against Children. UNICEF Web site. http:// www.unicef.org/protection/files/Violence_against_ Children.pdf. Accessed February 12, 2010.

35. Ministry of Women and Child Development. Study on Child abuse India 2007. India: MWCD; 2007.

36. Shumba A. Who guards the guards in schools? A study of reported cases of child abuse by teachers in Zimbabwean secondary schools. Sex Education 2001;1:77-86.

37. Appiah CD, Cusack K, editors. Violence against Women and Children in Ghana: report of a national study on violence. Accra, Ghana: Gender Studies and Human Rights Documentation Centre; 1999.

38. Blaya C, Debarbieux E. Expel violence! A systematic review of interventions to prevent corporal punishment, sexual violence and bullying in schools. Bordeaux: International Observatory on Violence in Schools; 2008. p.70.

39. Jewkes $\mathrm{R}$, Abrahams $\mathrm{N}$. The epidemiology of rape and sexual coercion in South Africa: an overview. Soc Sci Med 2002;55:1231-44. 
40. UNICEF. Corporal Punishment in Schools in South Asia. Kathmandu: UNICEF. http://www.crin.org/docs/ resources/treaties/crc.28/UNICEF-SAsia-Subm.pdf. Published 2001. Accessed February 12, 2010.

41. Leung PWS, Wong WCW, Chen WQ, Tang CSK. Prevalence and determinants of child maltreatment among high school students in Southern China: A large scale school based survey. Child Adolesc Psychiatry Ment Health 2008;2:27.

42. Save the Children/UNICEF/Government of NFWP. Disciplining the Child: Practices and Impacts. Pakistan: Save the Children/UNICEF/Schools and Literacy Dept; 2005.

43. Durrant, J.E. Trends in youth crime and wellbeing since the abolition of corporal punishment in Sweden. Youth Soc 2000;31:437-455.

44. Juvenile Justice System in Nepal. An act to provide for safe guarding the interests of children. Nepal Gazette May1992.

45. Newell P. Briefing from Global initiative to end all corporal punishment of children. Global Initiative. http://www.endcorporalpunishment.org/pages/ pdfs/briefings/CESCR\%20briefing\%20NovDec\%202006.pdf. Published November/December 2006. Accessed February 22, 2010.

46. Lawfulness of corporal punishment. http://www. endcorporalpunishment.org/pages/progress/ reports/nepal.html. Published 2007. Accessed March 2, 2010.

47. Joshi M. Corporal punishment continues to be a bugbear in schools. My Republica. October 6, 2009. http://www.myrepublica.com/portal/index. php?action=news_details\&news_id=10492. Accessed February 10, 2010.

48. Whipple EE, Richey CA. Crossing the line from physical discipline to child abuse: how much is too much? Child Abuse Negl 1997 May;21:431-44.

49. Chaturvedi BK. Chanakya Neeti. New Delhi110002: Diamond Pocket Books Pvt. Ltd.; p. 89.

50. UNICEF ROSA. Interviews with teachers and children in Kathmandu. 2000.

51. Hayward, Finney R. Breaking the earthenware jar: lessons from South Asia to end violence against women and girls. New York: UNICEF; 2000.

52. Groce N, Traci R. Rape of individuals with disability: AIDS and the folk belief of virgin cleansing. Lancet 2004;363:1663-4.
53. Jabeen S. Physical and psychological punishment of girls and boys in south Asia. Save the Children Sweden. http://www.sacg.info/pdf/PPP_paper_ to_be_presented_to_Ministers2.pdf. Accessed February 12, 2010.

54. The state of Children of Nepal 2009. Nepal Government, Ministry of Woman and Children, Kendriya Baal Kalyan Samiti; Bhadra 29, 2066.

55. Anti-corporal punishment training to be started. The Rising Nepal December 30, 2005.

56. UNICEF/CVICT. Violence Against Children in Nepal Series 2, A Study of the System of School Discipline in Nepal. UNICEF Web site http://www.unicef.org/ nepal/Voilence_Against_Children_series_2.pdf. Published 2004. Accessed February 2, 2010.

57. Nepal briefing. Save the children Web site. http:// www.savethechildren.net/alliance/what_we_do/ rewritethefuture/where/nepal.html. Accessed March 2, 2010.

58. UNICEF. Innocenti Occasional Papers, Child Rights Series No 9;1994.

59. Cameron M. Managing school discipline and implications for school social workers: a review of literature. Child Sch 2006;28:219-27.

60. deZoysa P, Newcombe PA, Rajapakse L. Consequences of parental corporal punishment on 12-year old children in the Colombo district. Ceylon Med J 2008 Mar;53(1):7-9.

61. Sweden/ EPOCH. The Child's Right to Physical Integrity and the UN Convention. Report to the UN Committee on the Rights of the Child from End Physical Punishment of Children Worldwide. 1993 Swedish Save the Children.

62. Karr-Morse R, Wiley MS. Ghosts from the Nursery; Tracing the Roots of Violence. New York: The Atlantic Monthly Press;1997.

63. Corcoran P, Gallagher J, Keeley HS, Arensman E, Perry IJ. Adverse Childhood Experiences and Lifetime suicide ideation: a cross-sectional study in a non-psychiatric hospital setting. Ir Med $\mathrm{J}$ 2006;99:42-5.

64. Tonmyr L, Jamieson E, Mery LS, MacMillan HL. The relation between childhood adverse experiences and disability due to mental health problems in a community sample of women. Can J Psychiatry 2005;50:778-83. 
65. Essali MA: Intervention in Child Abuse and Neglect: an Emerging Subspeciality in child and adolescent psychiatry. World Psychiatry 2005;4:160.

66. Spataro J, Mullen PE, Burgess PM, Wells DL, Moss SA: Impact of child sexual abuse on mental health: Prospective study in males and females. $\mathrm{Br}$ J Psychiatry 2004;84:416-21.

67. Child Sexual Abuse and Violence. WHO Regional Office for South-East Asia Web site. http:// www.searo.who.int/LinkFiles/Disability,_Injury_ Prevention_\&_Rehabilitation_child.pdf. Accessed February 12, 2010.

68. Ryan RM, Deci EL. Self-determination theory and facilitation of intrinsic motivation, social development and well-being. American Psychol 2000;55:68-78.

69. Sharma NP. Fulfillment of Children's Autonomy Need at School of Kathmandu Valley. Web site. http://narayansharma.academia.edu/ documents/0072/7713/Autonomy_Research_in_ School.pdf. Published 2007. Accessed, 2010.

70. Smith D, Smith PK, Ananiadou K. The Effectiveness of Whole-School Antibullying Programs: A Synthesis of Evaluation Research. School Psych Rev 2004;33:548-61.
71. Payne A, Gottfredson D, Gottfredson G. School predictors of the intensity of implementation of school-based prevention programs: results from a national study. Prevention Science 2006;7: 22537.

72. Gottfredson GD, Gottfredson DC. Victimisation in schools. In the Expel violence! Report. NewYork: Plenum Press;1985.

73. Ateah CA, Secco ML, Woodgate RL. The risks and alternatives to physical punishment use with children. J Pediatr Health Care 2003;17:126-32.

74. UNICEF.Voilence against children in Nepal Series 3.Health Practitioners' Knowledge, Attitude, and Practice on Child Abuse and Sexual Abuse in Nepal

75. Anti-corporal punishment training to be started. The Rising Nepal December 30, 2005.

76. UNESCO. Education in Crisis: The Impact and Lessons of the East Asian Financial Shock, 19971999. http://www.livingvalues.net. Published 2000. Accessed February 12, 2010.

77. Thapa M. Young Champions for Education: A Progress Review Final Report. UNGEI/UNICEF; 2010. 